\title{
Investigation of Fear of Crime in City Centers through the Example of Beşiktaş Sinanpaşa Neighborhood
}

\author{
Elif Köklü1, Funda Yirmibeşoğlu² \\ ${ }^{1}$ Istanbul Technical University, Institute of Science, Urban Design Department, Istanbul, Turkey \\ ${ }^{2}$ Istanbul Technical University, Faculty of Architecture, Department of Urban and Regional Planning, Istanbul, Turkey \\ Email: koklue@gmail.com,funday@itu.edu.tr
}

How to cite this paper: Köklü, E., \& Yirmibeşoğlu, F. (2017). Investigation of Fear of Crime in City Centers through the Example of Beşiktaş Sinanpaşa Neighborhood. Current Urban Studies, 5, 356-378. https://doi.org/10.4236/cus.2017.53020

Received: July 3, 2017

Accepted: September 16, 2017

Published: September 19, 2017

Copyright (c) 2017 by authors and Scientific Research Publishing Inc. This work is licensed under the Creative Commons Attribution International License (CC BY 4.0).

http://creativecommons.org/licenses/by/4.0/

\begin{abstract}
Physical and social structures of urban spaces may cause them to turn into crime areas or areas that can create fear of crime. Fear of crime is an important urban problem which affects the quality of life in cities as much as the crime cases themselves. Personal safety and the need for protection from crime have a considerably critical place among the issues to take into account during urban design and planning. The aim of the present study is to explain fear of crime as a problem which affects the life quality negatively in the city centers that turn into crime areas with urbanization and to determine the factors causing this situation. With this aim in mind, a questionnaire study has been carried out in Beşiktaş Sinanpaşa Neighborhood to evaluate the safety perception of the users and to identify the factors creating the perception of unsafety. In addition, the relationship between fear and space structure has been examined by using the space syntax method. As a result of the study, it is determined that the relationship between fear of crime and environmental factors is relatively stronger than the relationship between fear and demographic factors. Accessibility of the environment, in addition to the factors such as overpopulation in urban space, desolateness, inadequate lighting, and graffiti-like elements in the area, has been found to contribute negatively to the increase of fear of crime.
\end{abstract}

\section{Keywords}

Urban Crime, Safety Perception, Fear of Crime, Urban Design, City Security

\section{Introduction}

The approach of urban design and urban and regional planning disciplines to fear of crime, which is a popular research subject for many disciplines such as 
criminology, law, sociology, and biology, is to reduce and regulate the inequalities and the environmental factors which may lead to crime events. Thus, it is intended to improve the life quality by creating safer environments (Düzgün, 2007). According to Maslow (1942), human needs are expressed in a hierarchical order; when needs in one step are provided for, needs in the upper step should be met. Hereunder the need for safety, which comes right after the most fundamental physical and biological needs, is highly important for a person to maintain his life in a healthy and quality way. In this regard, to design safe environments in the urban area that we live in, fear of crime, which is as effective as crime events themselves, has to be minimized.

All of the political and social changes emerging as a result of economic development processes have caused cities to convert into today's contemporary areas. The most important factors for the emergence and development of modern cities are industrialization and excessive immigration from rural areas to cities due to various employment opportunities (Gökulu, 2010). With the studies carried out in the 1920s in Chicago by Shaw and McKay (1942), the relationships between crime events and urbanization were investigated. These studies argue that inadequate opportunities coming along with the growth in the city and worsening conditions lead to crime events (Shaw and McKay, 1942).

Wage gap, which came along with globalization, has caused class differences to appear (Ataç, 2008). As a result of these class differences, disintegration and divided areas have been formed inside the city (Gürbüz, 2015). Communities that are separate and disturbed from one another, and alienation and unsafety in the city pave the way for fear (Robert \& Pottier, 2002).

An important issue coming along with crime events is the fear of crime. Due to fear of crime, communication between human beings is decreasing. This decrease in communication brings about alienation in society. Studies with the intention of reducing and preventing crime are affected negatively from this situation (Dolu et al., 2010). While there are many international studies on fear of crime, not many studies in this regard have been done in Turkey. However, in order to create safe urban areas and improve our life quality, the subject of fear of crime should not be overlooked.

Relevant studies in the literature suggest that crime rates are more widespread in historical city centers and surrounding areas-areas with less population and heavy mixed-land use (Ergun \& Yirmibesoğlu, 2007). In regards with the distribution of fear of crime throughout Istanbul during daytime, it is suggested to be centered in the northern and eastern districts in the Anatolian side, and in the districts near Bosporus in the European side, which covers the historical centre of Istanbul. Being one of the districts near Bosporus in the European side, Beşiktaş is an important sub-center, located closely to historical city centers, Eminönü and Beyoğlu. Although crime rates are lower than those in the historical centers, it is seen that the fear of crime is experienced at almost the same level (Bilen et al., 2013). 
Fear of crime is as important a problem as the crime events in city centers and the aim of the present study is to analyze what factors fear of crime depends on, how it varies, how it is related to the space setup, and what kind of consequences it has, based on the sampling of Beşiktaş Sinanpaşa Neighborhood.

\section{The Concept of Fear of Crime and Fear of Crime Experienced in Urban Space}

Fear of crime is an important factor reducing the life quality of people living in cities. Experiencing the urban area in a more limited and cautious way due to fear of crime, citizens start to socialize less and less in time. This situation causes communication to gradually break down among people living in the same society and all these consequences lead to alienation in the society. It is extremely important and necessary to reduce fear of crime, as much as to reduce crime rates, in order to create a healthy urban environment and to experience the urban space comfortably and actively (Ergun \& Yirmibeşoğlu, 2016). Fear of crime does not have one single definition as it is studied by different disciplines. Ferraro (1995) explained fear of crime as an anxiety reaction towards a crime event or towards the elements people relate to the crime event. According to Pain (2000), fear of crime is an anxiety disorder which exists within the individual. Considering the studies about fear of crime, it is suggested that this condition is either inborn to the individual or develops depending on different factors. An individual, depending on the physical conditions of his environment, can develop a fear of crime reaction as a result of what he learns from his surroundings, from news or from any kind of environment that is easily accessible such as social media (Dolu et al., 2010).

In the relevant literature, fear of crime is studied primarily under two titles; on a social level and a personal level (Boers, 2003). Generally speaking, the factors causing fear of crime are listed as the physical condition of the environment, ethnicity, age, gender, socio-demographic structure, media, and personal experiences (Çardak, 2011). According to fear of crime theories based on individual investigations, being a victim of a crime or having someone around who is a victim of a crime is the source of experiencing fear of crime. It is suggested that the victim develops fear as a result of his own suffering, and also the negative experiences of the people around him can trigger this fear (Fattah, 1993; Winkel, 1998; Melde, 2007). Moreover, there is research that have put forth that physically weaker groups of people such as women, the elderly and children experience fear of crime more intensely (Chadee \& Ditton, 2003; Sutton \& Farral, 2005; Stanko, 1992). According to the studies investigating fear of crime on a social level, negative physical conditions like the presence of an abandoned building in the environment, inadequate lighting, graffiti, and additional factors like the presence of drunk people and drug addicts are all factors leading to fear (Hope \& Hough, 1998; Skogan \& Maxfield, 1981). Social disorganisation and heterogeneous social structures which have come along with urbanization are 
explained as factors causing fear of crime on a social level, too (Hope \& Hough, 1998; Başıüyük \& Karakuş, 2010).

There is a reciprocal interaction between fear of crime and the populated urban space (Ataç, 2007). Fear of crime affects people's usage preferences within the urban space. Individuals experiencing fear give up using some areas or change their daily routes (Yilmaz, 2006). Therefore, abandoned and unfunctional spaces appear in the city, which makes the individual dissatisfied with the environment as a result of feeling unsafe. The emergence of abandoned and avoided areas causes the environment to be more unsafe and this way there appears a reciprocal interaction (Wekerle \& Whitzman, 1995). Defined living spaces such as areas with old or illconditioned structures, and shanty settlements appearing as a consequence of the heterogeneous structure with immigration or collective housing areas are places where fear is highly perceived. At the same time, having lots of visibility by others in an environment is an important factor affecting the safety perception of an individual positively. Factors like roadway width, landscape elements, lighting are important design units that are effective in creating a perception of safety (Ataç, 2007). According to the studies, the relationship between fear of crime and physical factors is more influential than the relationship between fear of crime and demographic structure (Ergun \& Yirmibeşoğlu, 2016).

When the crime events in the cities are examined, it is seen that crime is not scattered randomly; certain crime types center on specific areas of the city. For example, high crime rates are seen in the surrounding areas of city centers and around commercial zones (Ergun \& Yirmibeşoğlu, 2016). In addition to the space usage, according to the literature studies on a different level of the relationship between the crime type and the spatial design, it is suggested that accessibility, choice and integration values are related to certain crime types. Studies within this framework suggest that the streets and main roads which are more accessible or have a high choice value are places with more crime events (Jones \& Fanek, 1997; Listerborn, 1999; Hillier \& Shu, 2000; Nubani \& Wineman, 2013).

Elements like doors and walls, which created a sense of safety in the city earlier, have lost their effect after modernization and fear of crime has become intensified in the cities (Çardak, 2011). According to Yılmaz (2006), there is an increase in fear of crime in parallel with the crime rates increasing with disconnection in the cities as a result of the heterogeneous social structure. According to the studies on the relationship between the space setup and the sense of unsafety and the fear of crime, there is a connection between fear of crime and the physical condition of the environment. It is suggested that the individual develops a fear of being a crime victim in the spaces which he has associated with a feeling of unsafety (Çardak, 2011; Snedker, 2011; Ferguson \& Mindel, 2007; Apak et al., 2002). According to a study, investigating how fear of crime differentiates between an urban space and a rural space in England by EUCPN (Europian Crime 
Preventing Network) in 2001, it is explained that the sense of fear of crime is higher in the cities than in rural areas due to a lack of social connection and solidarity (Çardak, 2011). Warr and Ellison (2000) defends that fear of crime is experienced more in the areas with higher population such as parks and industrial zones, whereas Sandstig (2010) claims that the minimal occupancy areas create more fear than do crowded places. Due to the physical condition of the structures intensified in the 1980s and ineffectiveness of works about fear, it is proved that individuals feel insecure and fear for being a crime victim in the neglected areas with inadequate lighting and graffiti (Tulloch, 2000; Keane, 1995; Smolej \& Kivivuari, 2006).

Nowadays, urban security and fear of crime constitute an important problem. Fear poses an obstacle for socialising, active urban usage, and experiencing a quality city life. In this study, spatial factors that create the fear of crime in Sinanpaşa Neighborhood, which constitutes the historical core of Beşiktaş District and which is an important subcenter with its closeness to historical city centers, are analyzed with the survey method and the space syntax method. In order to evaluate the safety perception of users in Sinanpaşa Neighborhood, Beşiktaş and to determine the causing factors as part of the study, 132 questionnaire studies (with \pm 8.3 confidence interval, 95\% reliability level) have been conducted. At the same time, the axial map of Sinanpaşa Neighborhood and surrounding areas has been generated; values of choice, connectivity and integration have been examined by using the space syntax method.

\section{Physical Condition, Development Process and Demographic Structure of Beşiktaş District}

Beşiktaş district is located within the provincial borders of Istanbul, in the southwest of the European side, near Bosphorus. The district is surrounded by Sarıyer in the north, Beyoğlu in the south, Şişli in the west and Bosphorus in the east (Image 1). Becoming a district municipality in 1984, Beşiktaş consists of Abbasağa, Akat, Arnavutköy, Bebek, Balmumcu, Cihannüma, Dikilitaş, Etiler, Gayrettepe, Konaklar, Kuruçeşme, Kültür, Levazım, Levent, Mecidiye, Muradiye, Ortaköy, Sinanpaşa, Türkali, Ulus, Yıldız and Vişnezade neighborhoods (Image 2).

Beşiktaş, which became a district municipality in 1984, consists of Abbasağa, Akat, Arnavutköy, Bebek, Balmumcu, Cihannüma, Dikilitaş, Etiler, Gayrettepe, Konaklar, Kuruçeşme, Kültür, Levazım, Levent, Mecidiye, Muradiye, Ortaköy, Sinanpaşa, Türkali, Ulus, Yıldız, and Vişnezade neighborhoods.

Having been located outside the city walls until the conquest of Istanbul and gaining district status after the conquest during the Ottoman period, Beşiktaş has always been an important center. The district became more important with the construction of the Dolmabahçe Palace and Galata Tower in the 17th century, and with the beginning of ferry cruises in the 19th century. Also in this period, the first version of collective housing in Turkey was built in Akaretler. In 


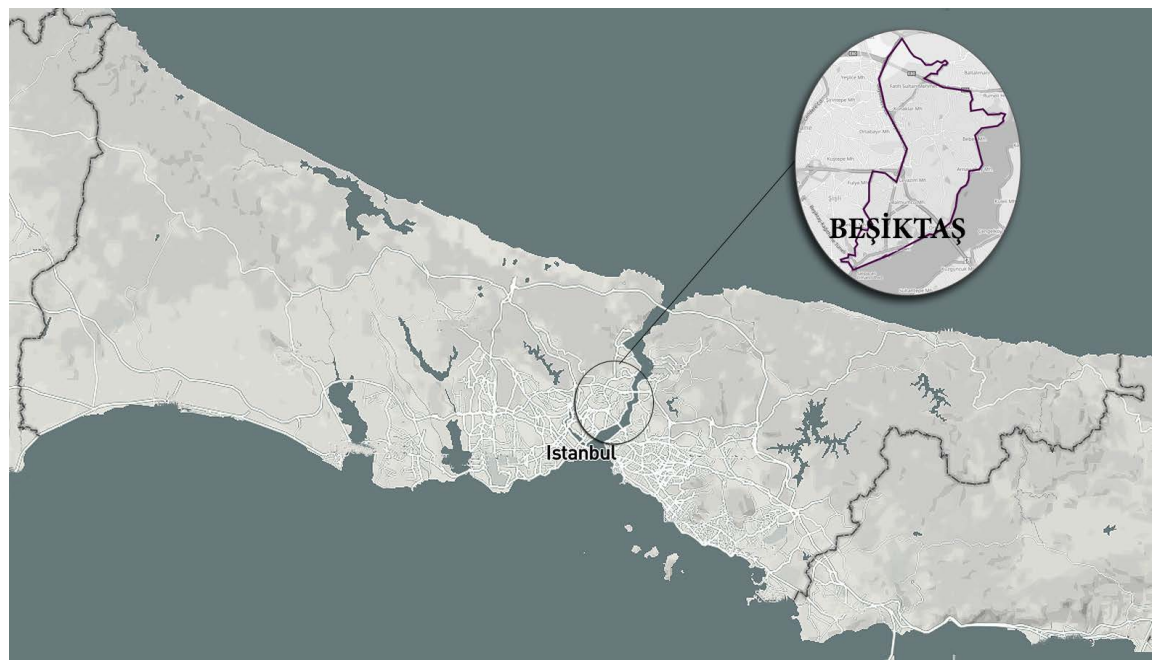

Image 1. The location of Beşiktaş district within Istanbul.

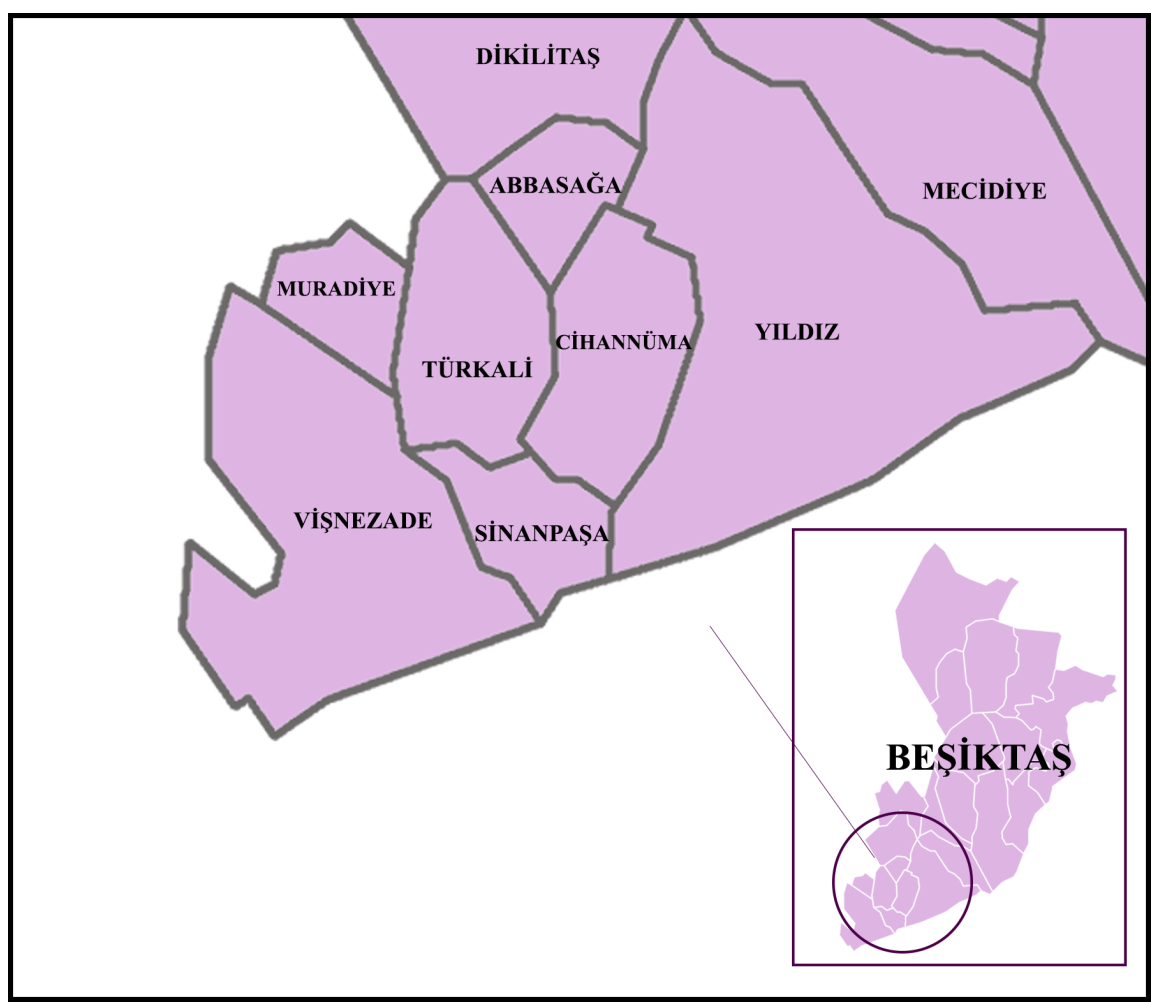

Image 2. The location of Sinanpaşa neighborhood within the Beşiktaş District.

the 20th century, with the abolition of the caliphate and the dynasty leaving the country, palace structures in the area lost their function; some of them were demolished, some were given to the state or educational institutions.

The quality of Zincirlikuyu-Beşiktaş and Ihlamurdere main roads were increased with the arrangements in Beşiktaş District within the scope of land use plan of Henri Prost, performed as part of the developments in Istanbul in 1938. Barbaros Square was established, Barbaros Shrine was brought into the open, 
and Barbaros monument was built. Abbasağa graveyard was removed and designed as a park, Taşlık and Vişnezade Parks were built, also Maçka Graveyard was removed and the road was expanded, and Yıldız Park was built. Bayıldım Slope, which connects Dolmabahçe and Maçka, was transformed into an observation terrace. After the 1950s, Levent and Ylldiz have become important neighborhoods standing out with business and service sector (Beşiktaş Municipality, 2016). In the 1970s Beşiktaş District was included in CBD (Central Business District) development zone and today it has a substantial place within the CBD with its featured business and service functions (Yenen et al., 2000).

According to the 2013 address-based population registration system data, the total population of Beşiktaş District is 186.570 . While men consist $46.62 \%$ of the district population, $53.38 \%$ are women. The population density of the district is 10.342 person $/ \mathrm{km}^{2}$, which is higher than the population density of Istanbul with 2.725 person $/ \mathrm{km}^{2}$. The general education level in Beşiktaş District is higher than the average of Turkey. While the average ratio for people with secondary and higher education is $34.6 \%$ in Turkey, this ratio in Beşiktaş is 63.25\% (Beşiktaş Municipality, 2016).

One of the oldest neighborhoods of Beşiktaş District is the Sinanpaşa Neighborhood, containing Köyiçi zone within itself, which is the historical core of the district. Sinanpaşa neighborhood is surrounded by Vişnezade Neighborhood in the West, Cihannüma and Türkali Neighborhoods in the North and Yıldız Neighborhood in the East (Image 2). According to the 2013 data, in the neighborhood constituting $1.31 \%$ of the total population of Beşiktaş District, there are 2449 residents.

In the vicinity of Sinanpaşa Neighborhood and especially in the upper part, the most common space usage is the house usage. At the center of the neighborhood, there are squares and around the center are mostly business, commercial and housing functions (Appendix 1).

Beşiktaş is a district close to Beyoğlu and Eminönü, historical city centers of Istanbul, where mixed usage is common; it has a low population density and is an important sub-center in the European side, in which the fear of crime is experienced often (Bilen et al., 2013). According to the crime data of 2007 within Istanbul, the crime rate in Beşiktaş is lower than that in the historical city centers, Eminönü and Beyoğlu, but the crime rate in the district is higher than the overall crime rate in Istanbul (Ergun \& Yirmibeşoğlu, 2007).

According to a district-based study on fear of crime conducted in Yildiz Technical University in 2013, the fear of crime in Beşiktaş is experienced at the same level as in the historical centers, Eminönü and Beyoğlu (Image 3) (Bilen et al., 2013).

There are studies carried out about the fear of crime within the historical centers, Eminönü and Beyoğlu. However, for Beşiktaş there has not been a study within this scope; even though the crime rates are low in Beşiktaş, which is an important sub-center, the fear of crime is experienced as intensely as in the 


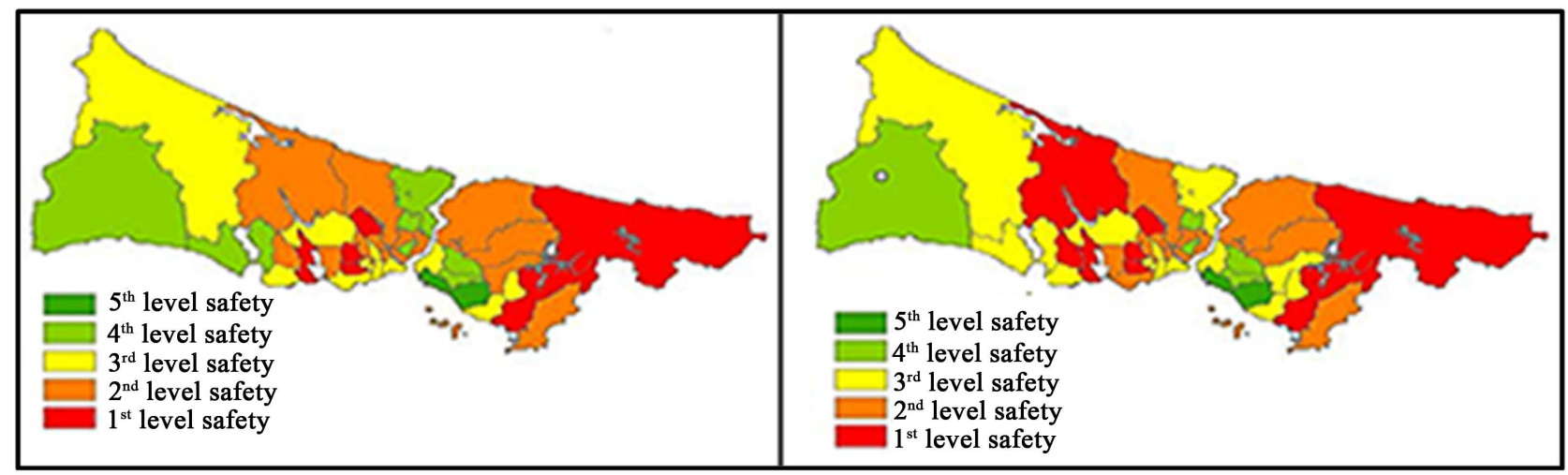

Image 3. Spatial distribution of the fear of crime in Istanbul during the day and the night (Bilen et al., 2013).

above-mentioned historical centers. The aim of the study is to analyze the relationship between the space usage and the fear of crime within the city centers and sub-centers which have busy human traffic and are important places within the city, through the example of Beşiktaş Sinanpaşa Neighborhood.

\section{The Fear of Crime Study within Beşiktaş Sinanpaşa Neighborhood}

A total of 132 questionnaire studies, consisting of 12 questions, were performed within the scope of the study in order to explain the relationship between the space usage preferences of individuals and the fear of crime in Beşiktaş Sinanpaşa Neighborhood. Additionally, the space syntax method is used in order to analyze the relationship between the spatial configuration and the fear of crime.

The size of the questionnaire survey is determined in such a way to represent the population of Sinanpaşa Neighborhood (8.3 confidence interval, 95\% reliability level). The questions within the questionnaire were prepared considering the following aims: 1) to identify the demographic backgrounds of the participants, 2) to identify the usage habits of the participants in Beşiktaş Sinanpaşa Neighborhood, 3) to identify the security perceptions of the participants and whether or not the participants or their relatives have been crime victims , 4) to identify the factors creating unsafety in the environment according to the participants and to identify the streets, in which they feel unsafe, 5) to identify in which space usage function the participants experience fear more densely, and 6) to measure if there is any renovation condition within the study area and its effect on the sense of safety.

1) The demographic background of the participants: The participants are mostly women (60.6\% women, $39.4 \%$ men), their age group is mainly between 21 - 30 (47\%); $47 \%$ of the participants were born in Istanbul and their educational level is high (university level education with a $56.1 \%$ ratio). The participants are mainly students (36.4\%). Most of the participants have been living in Istanbul for 20 - 30 years (27.3\%). The questionnaire study was performed on 
the same level for both the users residing in the area and the visitors $(44.7 \%$ of the users residing in the center and vicinity, $55.3 \%$ of the users residing outside the center) (Appendix 2).

2) The usage habits of the participants in Beşiktaş Sinanpaşa Neighborhood: Considering the purpose of visit of the participants to Sinanpaşa Neighborhood (except the residing users with the highest ratio of $43.2 \%$ ), visitors come to the area mostly for entertainment purposes (37.9\%), and education is the least popular purpose of visit (8.3\%). The participants visit the area on a daily basis in general at a high ratio of $50 \%$ (Appendix 3 ).

3) The security perceptions of the participants and whether or not the participants or their relatives have been crime victims: The participants find Beşiktaş Sinanpaşa Neighborhood safe in both day time and night time in general and they are not afraid of going out alone (day time safety $82.6 \%$, night time safety $62.1 \%$, not being afraid of going out alone $93.9 \%$ ). Also it is determined that the ratio of being a crime victim in Beşiktaş among the participants and their relatives is extremely low $(12.9 \%$ of the participants, $15.3 \%$ of their relatives are crime victims) (Appendix 4).

4) The factors creating a sense of unsafety in the environment according to the participants, and the streets, in which they feel unsafe: As for the reasons why the participants find Beşiktaş unsafe during day time, the results are the risk of a possible terrorist attack with the highest ratio (32\%), followed by the crowd (17\%), and the risk of exposure to crimes such as purse snatching (13\%). On the other hand, the participants who think Beşiktaş is unsafe during night time reported the presence of drunk people with the highest ratio (18\%), desolateness (15\%) and the presence of drug addicts (13\%) as reasons (Appendix 5). Within the scope of the survey study, the participants were asked to rate the elements creating unsafety in the environment from 1 to 6,1 being the most unsafe. Thus, the element which creates a perception of unsafety the most is determined to be the terrorist incidents taking place throughout the country. Following this are factors such as people in the environment, usage in the environment, crumbling environments, isolated environments and the lack of lighting respectively (Figure 1). Furthermore, the streets in which participants feel unsafe are determined as Beşiktaş bazaar area (28\%), Beşiktaş Square (15\%), Ihlamurdere Main Road (11\%), the surroundings of Sinanpaşa Mosque, Mumcu Bakkal Street, Mısırlı Bahçe Street, Dolmabahçe Main Road, Beşiktaş Main Road, Salihefendi Street, Şair Veysi Street, the surroundings of Tuzcubaba, Hasfirın Street, Şair Nedim Main Road, Afacan Street, and Barbaros Boulevard (Appendix 6).

5) When we look at the map obtained through overlapping the land use map of Sinanpaşa Neighborhood and the streets creating unsafety for the participants of the survey, it is seen that the areas creating the highest feeling of unsafety for the participants are mostly commercial and culture areas, and squares (Beşiktaş bazaar area, Beşiktaş Square, Ihlamurdere Main Road) (Appendix 8). 


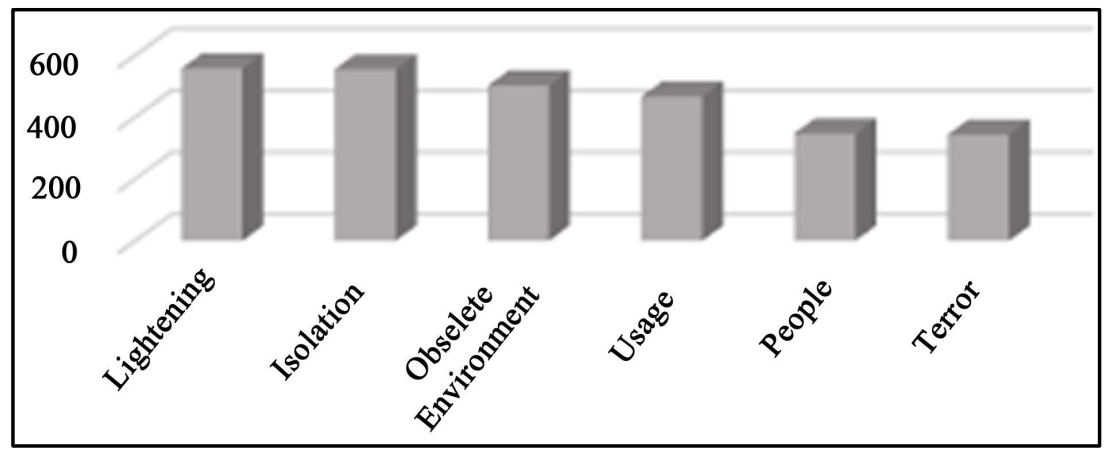

Figure 1. Assessment of the elements creating fear according to the participants.

6) Whether or not there is any renovation work within the study area and its effect on the sense of safety: One part of the questionnaire study was performed around the renovation areas (25\%); however, most of the participants stated that renovations do not affect their sense of safety (75\% neutral) (Appendix 7).

In regards with the correlation analysis results obtained from the survey data, it is seen that, among all the reported factors creating the sense of unsafety, the gender of the participants is positively correlated with the usage of elements in the environment, and negatively correlated with the safety condition after the renovation process (Table 1 ).

With the binary regression analyis based on this correlation, the safety condition after the renovation is determined as a dependent variable and the gender factor as an independent variable; with the multiple regression, the safety condition after the renovation is determined as a dependent variable and gender, age groups, educational status, place of residence, period of residence, and educational level as independent variables. Hereunder there is a significant correlation between the assessment of the safety condition after the renovation and the demographic data; the most effective one among these factors is the gender factor (Table 2).

The streets in which the participants feel unsafe in Sinanpaşa Neighborhood and surroundings are determined and pinpointed on the map, based on the data acquired from the survey results, in order to analyse the relationship between fear of crime and the formation of the environment. Afterwards, the choice, integration and connectivity maps of these areas are created via the space syntax method.

According to the choice map, Sinanpaşa Neighborhood and surroundings are the major axials of Beşiktaş and at the same time it is found out that the choice values of the streets connecting the area to the surrounding districts have the highest choice value in the zone. The streets with the lowest choice value turns out to be the innermost areas of the region-the areas without a decent and incessant structure.

Examined comparatively, there is a consistence between the connectivity map and the choice value map, both of which were obtained with the space syntax 
Table 1. Correlation analysis according to gender.

\begin{tabular}{lll}
\hline $\begin{array}{l}\text { Fear of Walking Alone, } \\
\text { Environmental Security, }\end{array}$ & & \\
$\begin{array}{l}\text { Purpose of Visit to Beşiktaş, } \\
\text { Frequency of Visiting Beşiktaş, }\end{array}$ & Gender Pearson Correlation & Sig. (2-tailed) \\
$\begin{array}{l}\text { Insecurity Elements, } \\
\text { Security After Renovation }\end{array}$ & & \\
\hline $\begin{array}{l}\text { Fear of Walking Alone } \\
\text { Day Time Safety }\end{array}$ & 0.75 & 0.394 \\
Night Time Safety & 0.043 & 0.622 \\
Purpose of Visit to Beşiktaş & -0.042 & 0.635 \\
Frequency of Visiting Beşiktaş & -0.83 & 0.346 \\
People in the Environment & -0.098 & 0.263 \\
Usage in the Environment & 0.054 & 0.540 \\
Crumbling Environment & $0.178^{*}$ & 0.041 \\
Desolateness & -0.027 & 0.758 \\
Terror & -0.118 & 0.179 \\
Renovated Area & -0.038 & 0.662 \\
Safety After Renovation & $0.215^{*}$ & 0.013 \\
\hline
\end{tabular}

${ }^{*}$ Correlation is distinct at 0.01 level (2-tailed). ${ }^{*}$ Correlation is distinct at 0.05 level (2-tailed).

Table 2. Safety after renovation and demographic data multiple regression analysis.

\begin{tabular}{|c|c|c|c|c|c|}
\hline \multirow{2}{*}{$\begin{array}{l}\text { Regression } \\
\text { Analysis }\end{array}$} & $\begin{array}{l}\text { Non-Standardized } \\
\text { Parameters }\end{array}$ & \multirow[t]{2}{*}{ Std. Error } & $\begin{array}{l}\text { Standardized } \\
\text { Parameters }\end{array}$ & \multirow[t]{2}{*}{$\mathrm{T}$} & \multirow[t]{2}{*}{ Sig. } \\
\hline & B & & Beta & & \\
\hline \multicolumn{6}{|c|}{ Dependant variable: Security After Renovation } \\
\hline (Constant) & 1.167 & 0.327 & & 3.563 & 0.001 \\
\hline Gender & 0.188 & 0.078 & 0.212 & 2.411 & 0.017 \\
\hline Age Groups & -0.018 & 0.039 & -0.059 & -0.467 & 0.641 \\
\hline Place of Birth & 0.007 & 0.017 & 0.044 & 0.410 & 0.683 \\
\hline Educational Status & 0.023 & 0.035 & 0.077 & 0.677 & 0.499 \\
\hline Occupation & 0.005 & 0.011 & 0.045 & 0.441 & 0.660 \\
\hline Period of Residence & 0.044 & 0.033 & 0.169 & 1.327 & 0.187 \\
\hline Place of Residence & 0.016 & 0.032 & 0.044 & 0.487 & 0.627 \\
\hline
\end{tabular}

method. The main roads with the highest connection value are determined to be the roads encircling the area and connecting the area with the surrounding environments. Moreover, interior streets are the axials with the lowest connection value. To this respect, it can be said that the most effective axials for determining the choice value are the axials with the highest connection value (Image 4). 


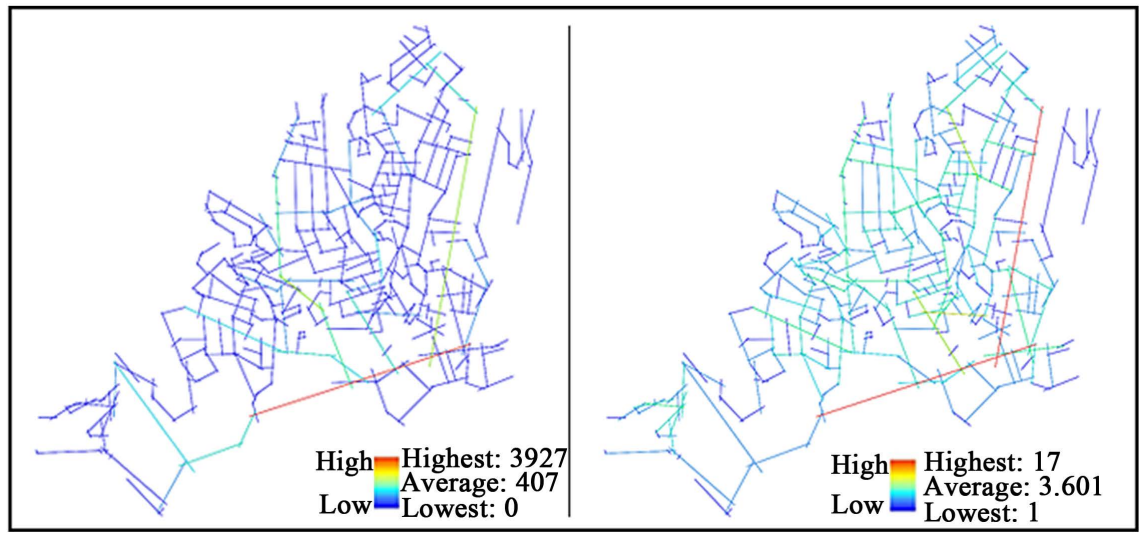

Image 4. Selection map and connection map of Sinanpaşa neighborhood.

According to the integration map values with regional and local scale, the area consisting of Beşiktaş bazaar zone has a high integration value. It is seen that the sectional interior streets with low connection value and low selection value, also have low integration value (Image 5). Containing the historical core of Beşiktaş, Sinanpaşa Neighborhood has an integrated structure in general. However, according to the data obtained from the questionnaire study in the zone, the streets in which the participants feel most unsafe are also mostly around this area (Image 6).

\section{Conclusions and Recommendations}

Studies about fear of crime demonstrate that the fear of crime affects the life quality of the individuals living in the cities in a considerably negative way. The sense of unsafety occuring after an individual is attacked or witnesses a crime situation in an urban space can cause conditions suchs weakened social bonds, social segreation, and emergence of various abandoned or defined areas in the city. Therefore, it is crucial to provide a safe environment by eliminating the fear of crime in the city.

According to the study carried out by Yıldiz Technical University in 2013, which analyses the distribution of fear of crime in the districts of Istanbul, in Beşiktaş District, which is an important sub-center highly close to the historical city centers Eminönü and Beyoğlu, and which has low population density and a widespread mixed usage, fear of crime is experienced nearly at the same level as in Eminönü and Beyoğlu, which have much higher crime rates (Bilen et al., 2013; Ergun \& Yirmibeşoğlu, 2007). The study investigated the elements creating a feeling of unsafety in Sinanpaşa Neighborhood, containing Köyiçi area, which forms the historical core of the Beşiktaş District, in which fear of crime has been found to be experienced at a high level.

The survey results obtained from the present study have shown that Beşiktaş Köyiçi users feel safe in the area during both the day and the night time. While the fear experienced in the area is very low, it is determined that the spatial factors affecting the sense of unsafety at most are the usage and the users in the 


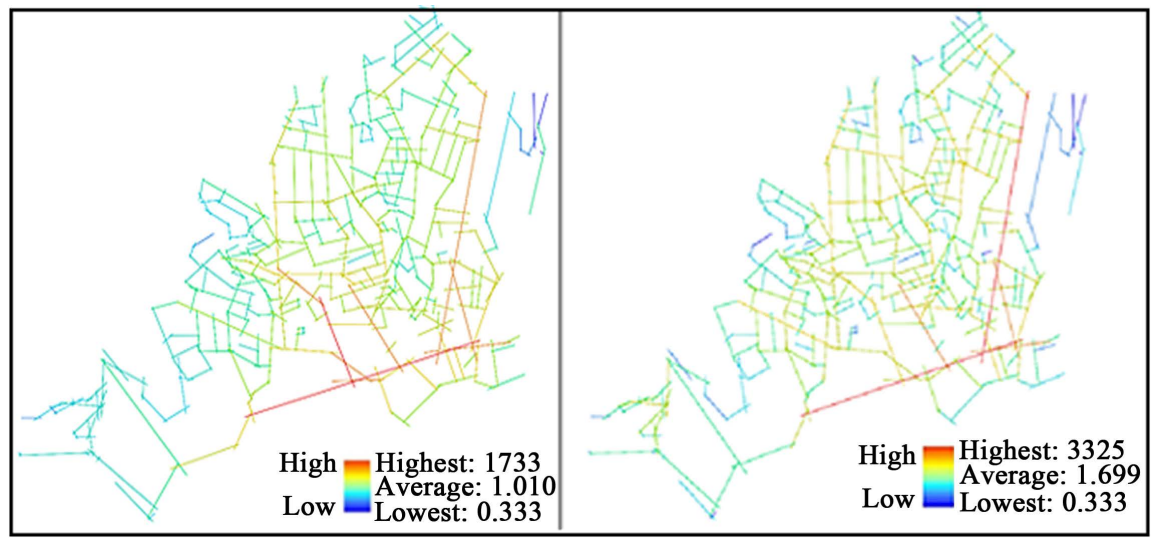

Image 5. General Integration and R3 Integration map of Sinanpaşa neighborhood.

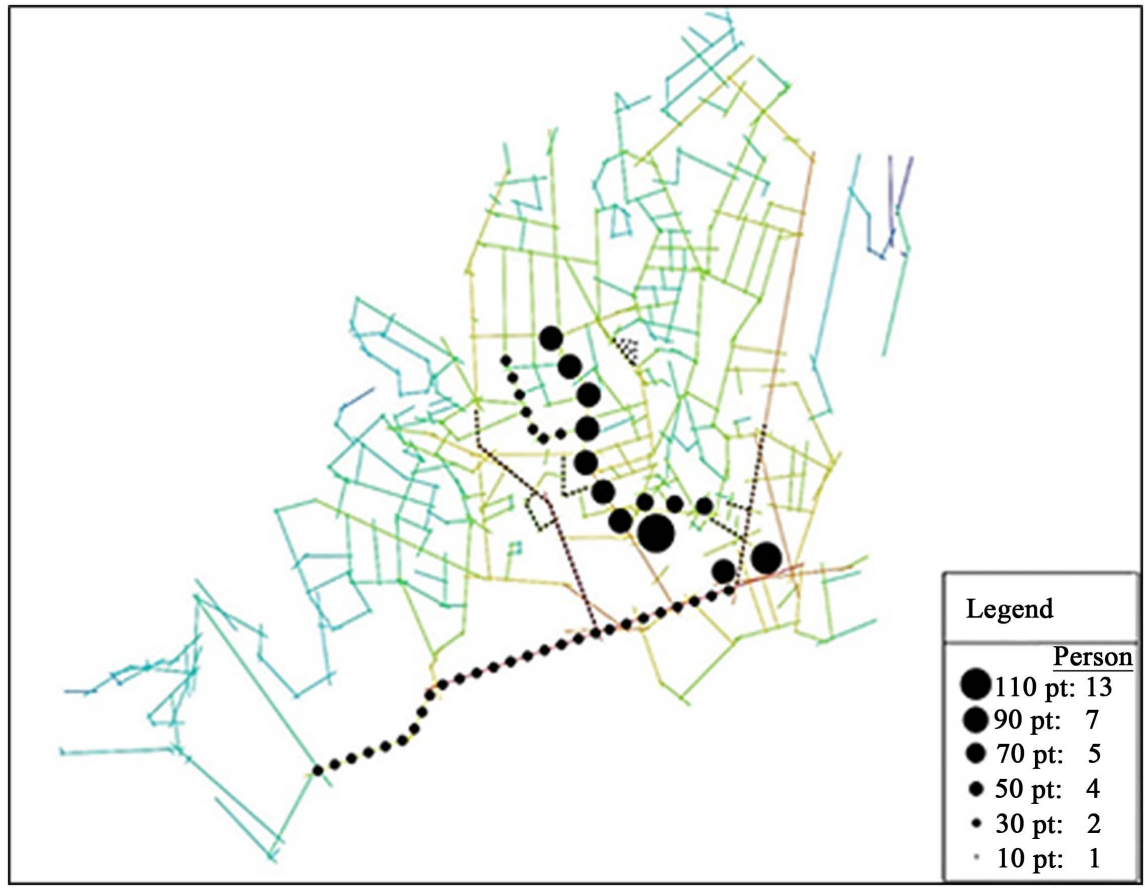

Image 6. Unsafety map and Integration values of Beşiktaş Sinanpaşa neighborhood according to the questionnaire data (Köklü, 2016).

environment. According to the previous research on the fear of crime in Istanbul (Bilen et al., 2013), the reason why the fear of crime, which is relatively high in Beşiktaş District, is lower in the study area, the core of Beşiktaş, is because the area is vivacious and used every hour of the day. Also, the common mixed usage in the area is another factor to decrease fear.

The streets and areas where the participants feel unsafe are usually overcrowded hotspots with widespread commercial business-service space usage, isolated streets, and the streets with stairs obstructing escape routes in case of a crime event (Appendix 9 and Appendix 10). It can be concluded that the obtained data in this sense is consistent and have parallels with the space features creating unsafety identified in the previous literature studies (Ergun \& 
Yirmibeşoğlu, 2015; Tulloch, 2000; Smolej \& Kivivuari, 2006).

The axial map of Sinanpaşa Neighborhood and surroundings has been created and the selection choice, integration and connectivity values have been examined. Accordingly, it is determined that the streets with high or medium level of choice and global integration values in the study area are places with higher levels of fear of crime. Streets with high values of integration and connectivity are easily accessible. Therefore, they are crowded, active and preferred by more people. This condition causes a development of an environment conducive to crime events in the street. Due to this, it is significant that the users indicate a fear in the streets with high values of connectivity and integration within the study area. Plenty of studies have been and are being done about fear of crime around the world. However, in Turkey, even though there have been studies by the government about identifying crime rates, not much has been said about the topic of fear of crime and there have not been many studies about this subject. When experienced at high levels, fear of crime is an important factor decreasing the life quality of individuals. Fear within the study area has been found to be scarce; however, it is determined that the spatial configuration of the area is related to fear. Therefore, it is seen that decreasing the conditions which can create unsafety within the urban space through design is necessary in order to promote a healthy city life. A safer environment should be created by popularizing mixed usage within the cities, transforming the areas with broken-down buildings and contributing them back to the city, and designing alternative routes in order to distribute the crowd equally. Also, the development of the current safety protocols should be provided by increasing the number and the variety of the studies about fear of crime.

\section{Acknowledgements}

This article is developed from the master thesis of Elif Köklü, entitled as "Analysing The Fear of Crime in City Centers: Example of Beşiktaş", prepared in Istanbul Technical University with the counseling of Prof. Dr. Funda Yirmibeşoğlu.

\section{References}

Apak, S., Ülken, G., \& Ünlü, A. (2002). Yeni bir toplu konut yerleşmesinde güvenlik duygusunun değerlendirilmesi. [Assessment of Security Perception in a New Housing Complex.] İtü Dergisi/a, 1, 65-72.

Ataç, E. (2007). The Perception of Crime in Urban Space; Feeling of insecurity. Issue 06, TMMOB Mimarlar Odası Ankara Şubesi, Journal 55, November-December 2007.

Ataç, E. (2008). Kent, güvenlik ve güvenli kent planlamasl; Bursa örneği (Yüksek lisans tezi). [City, Security and Safe Urban Planning; Bursa Example (Master Degree Thesis).] Ankara: Gazi Üniversitesi, Fen Bilimleri Enstitüsü.

Başıbüyük, O., \& Karakuş, Ö. (2010). Sosyal düzensizlik ve toplum destekli güvenlik politikalar1. [Social disorganization and community-supported security policies.] Türkiye Sosyoloji Araştırmaları Dergisi, 13, 65-97.

Beşiktaş Belediyesi. [Besiktas Municipality Publishing.] http://www.besiktas.bel.tr/ 
Bilen, O., Aşkın, O. H., Okten, A., \& Gur, M. (2013). How the Fear of Crime Spatially Differs among the Districts of Istanbuli. NWSA-Social Sciences, 8, 153-164.

Boers, K. (2003). Crime, Fear of Crime and the Operation of Crime Control in the Light of Victim Surveys and Other Empirical Studies. In 22nd Criminological Research Conference (pp. 24-26). Munster University.

Chadee, D., \& Ditton, J. (2003). Are Older People Most Afraid of Crime? British Journal of Criminology, 43, 417-433. https://doi.org/10.1093/bjc/43.2.417

Çardak, B. (2011). Ankara'da yaşayan kadınlarda suç mağduru olma korkusu üzerine nitel bir çalışma (Yayımlanmamış yüksek lisans tezi). [A Qualitative Study on the Fear of Crime Victimization in Women Living in Ankara (Unpublished Post Graduate Thesis).] Ankara: T.C. Kara Harp Okulu.

Dolu, O., Uludağ, Ş., \& Doğutaş, C. (2010). Fear of Crime: Causes, Consequences and Security Policies. Ankara University SBF Journal, 65, 57-81.

Düzgün, Ş. (2007). Suç olgusuna teorik yaklaşımlar ve disiplinlerarasılık. [Theoretical Approaches and Interdisciplinarity to Crime Issue.] TMMOB Ankara Şubesi Bülteni, 6, 4-10.

Ergun, N., \& Yirmibeşoğlu, F. (2007). Distribution of Crime Rates in Different Districts in Istanbul. Turkish Studies, 8, 435-455.

https://doi.org/10.1080/14683840701489324

Ergun, N., \& Yirmibeşoğlu, F. (2015). Fear of Crime among Women in the Old City Center of Istanbul. Current Urban studies, 3, 161-174.

https://doi.org/10.4236/cus.2015.32014

Ergun, N., \& Yirmibeşoğlu, F. (2016). Differences Fear of Crime between Residents and Visitors in the Old City Center of Istanbul. Valley International Journals, 3, 3106-3122.

Fattah, E. A. (1993). Victimisation and Fear of Crime among the Elderly: A Possible Link? Canberra: Australian Institute of Criminology. http://www.aic.gov.au/media_library/conferences/olderpeople/fattah.pdf

Ferguson K. M., \& Mindel C. H. (2007). Modeling Fear of Crime in Dallas Neighborhoods: A Test of Social Capital Theory. Crime \& Deliquency, 53, 322-349. https://doi.org/10.1177/0011128705285039

Ferraro, K. F. (1995). Fear of Crime, Interpreting Victimization Risk. New York, NY: Suny Research \& Forecast Inc.

Gökulu, G. (2010). Kent güvenliği, kentleşme ve suç ilişkisi. [Urban security, urbanization and crime relation.] Atatürk Üniversitesi Íktisadi ve Ídari Bilimler Dergisi, 24, 209-226.

Gürbüz, D. (2015). Türkiye'de kentleşme sürecinde çöküntü bölgesi ve suç ilişkisi: Hacıbayram Mahallesi örneği. [The Process of Urbanization in Slum Areas and Crime Relation in Turkey: Sample of Hacıbayram Neigbourhood.] Akademik Bakış Dergisi, $47,1-15$.

Hillier, B., \& Shu, S. (2000). Crime and Urban Layout: The Need for Evidence. In S. Bal-lintyne, K. Pease, \& V. McLaren (Eds.), Secure Foundations: Key Issues in Crime Prevention, Crime Reduction and Community Safety (pp. 224-248). London: IPPR.

Hope, T., \& Hough, M. (1998). Community Approaches to Reducing Crime. In T. Hope, \& M. Shaw (Eds.), (pp. 1-29). London: Communities and Crime Reduction (Her Majesty's Stationary Office).

Jones, M., \& Fanek, M. (1997). Crime in the Urban Environment. In M. D. Major, L. Amorim, \& F. Dufoux (Eds.), Proceedings of the 1st International Space Syntax Symposium, Vol. II, London, 25.1-25.11. 
Köklü, E. (2016). Kent merkezlerinde suç korkusunun incelenmesi: Beşiktaş örneği (Yüksek lisans tezi). [Investigation of Fear of Crime In City Centers: Beşiktaş Sample.] İstanbul: İstanbul Teknik Üniversitesi, Fen Bilimleri Enstitüsü.

Listerborn, C. (1999). Women's Fear and Space Configurations. In Proceedings of the 2nd International Symposium on Space Syntax.

http://www.spacesyntax.net/symposia-archive/SSS2/SpSx\%202nd\%20Symposium\%209 9\%20-2003\%20pdf/2nd\%20Symposium\%20Vol\%202\%20pdf/51\%20Listerborn $\% 20300$. pdf

Maslow, A. H. (1942). The Dynamics of Psychological Security-İnsecurity. Journal of Personality, 10, 331-344. https://doi.org/10.1111/j.1467-6494.1942.tb01911.x

Melde, E. C. (2007). Peer-Group Composition and the Percieved Risk of Victimization: Modeling Fear of Crime in a School-Based Sample. Unpublished PHD Thesis, St. Louis: University of Missouri Criminology and Criminal Justice.

Nubani, L., \& Wineman, J. (2013). The Role of Space Syntax in Identifying the Relationship between Space and Crime. Journal of Chemical Information and Modeling, 53, 1689-1699.

Pain, R. (2000). Place, Social Relations and the Fear of Crime: A Review. Progres in Human Geography, 24, 365-388. https://doi.org/10.1191/030913200701540474

Robert, P., \& Pottier, M. (2002). Crime et securite; L'etat des savoirs. [Crime and Security; The State of Knowledge.] Çeviren: Veysel Er, Polis Dergisi, 39, 13-24.

Sandstig, G. (2010). Media İnfluences and Effects on Experiences of Uncertainty and Fear in Urban Spaces. Journal of US-China Public Administration, 7, 66-84.

Shaw, C. R., \& McKay, H. D. (1942). Juvenile Delinquency in Urban Areas. Chicago: University of Chicago Press.

Skogan, W. G., \& Maxfield, M. G. (1981). Coping with Crime: Individual and Neighbourhood Reactions. Beverly Hills, CA: Sage.

Smolej, M., \& Kivivuori, J. (2006). The Relation between Crime News and Fear of Violence. Journal of Scandinavian Studies in Criminology and Crime Prevention, 7, 211-227. https://doi.org/10.1080/14043850601002429

Snedker, A. K. (2011). Neighborhood Conditions and Fear of Crime: A Reconsideration of Sex Differences. Crime \& Delinquency, 61, 1-26.

Stanko, E. A. (1992). The Case of Fearful Women: Gender, Personal Safety and Fear of Crime. Women and Criminal Justice, 4, 117-135.

https://doi.org/10.1300/J012v04n01_06

Sutton, R. M., \& Farrall, S. (2005). Gender, Socially Desirable Responding and the Fear of Crime: Are Women Really More Anxious about Crime? British Journal of Criminology, 45, 212-224. https://doi.org/10.1093/bjc/azh084

Tulloch, M. (2000). The Meaning of Age Differences in the Fear of Crime. British Journal Criminol, 40, 451-467. https://doi.org/10.1093/bjc/40.3.451

Warr, M., \& Ellison, C. G. (2000). Rethinking Social Reactions to Crime: Personal and Altrustic Fear in Family. American Journal of Sociology, 106, 551-578.

https://doi.org/10.1086/318964

Wekerle, G. R., \& Whitzman, C. (1995). Safe Cities: Guidelines for Planning, Design and Management (pp. 5-25). A Division of International Thomson Publishing.

Winkel, F. W. (1998). Fear of Crime and Criminal Victimization: Testing a Theory of Psychological Incapacitation of the "Stressor" Based on Downward Comparison Processes. British Journal of Criminology, 38, 473-484.

https://doi.org/10.1093/oxfordjournals.bjc.a014258 
Yenen, Z., Akın, O., \& Yakar, H. (2000). Eyüp DönüGüm Sürecinde Sos-yalEkonomik-Mekansal Yapı, Eyüp Belediyesi Yayını, İstanbul. [Social-Economic-Spatial Structure in the Eyüp Transformation Process, Eyüp Municipality Publishing.]

Yılmaz, G. (2006). Türkiye'de suç ve suçluluk olgusunun kentleşme bağlamında irde-lenmesi (Yayımlanmamış Yüksek Lisans Tezi). [The Analysis of Crime and Guiltiness in the Context of Urbanization in Turkey (Unpublished Master Thesis).] İstanbul: İstanbul Teknik Üniversitesi, Fen Bi-limleri Enstitüsü. 


\section{Appendixes}

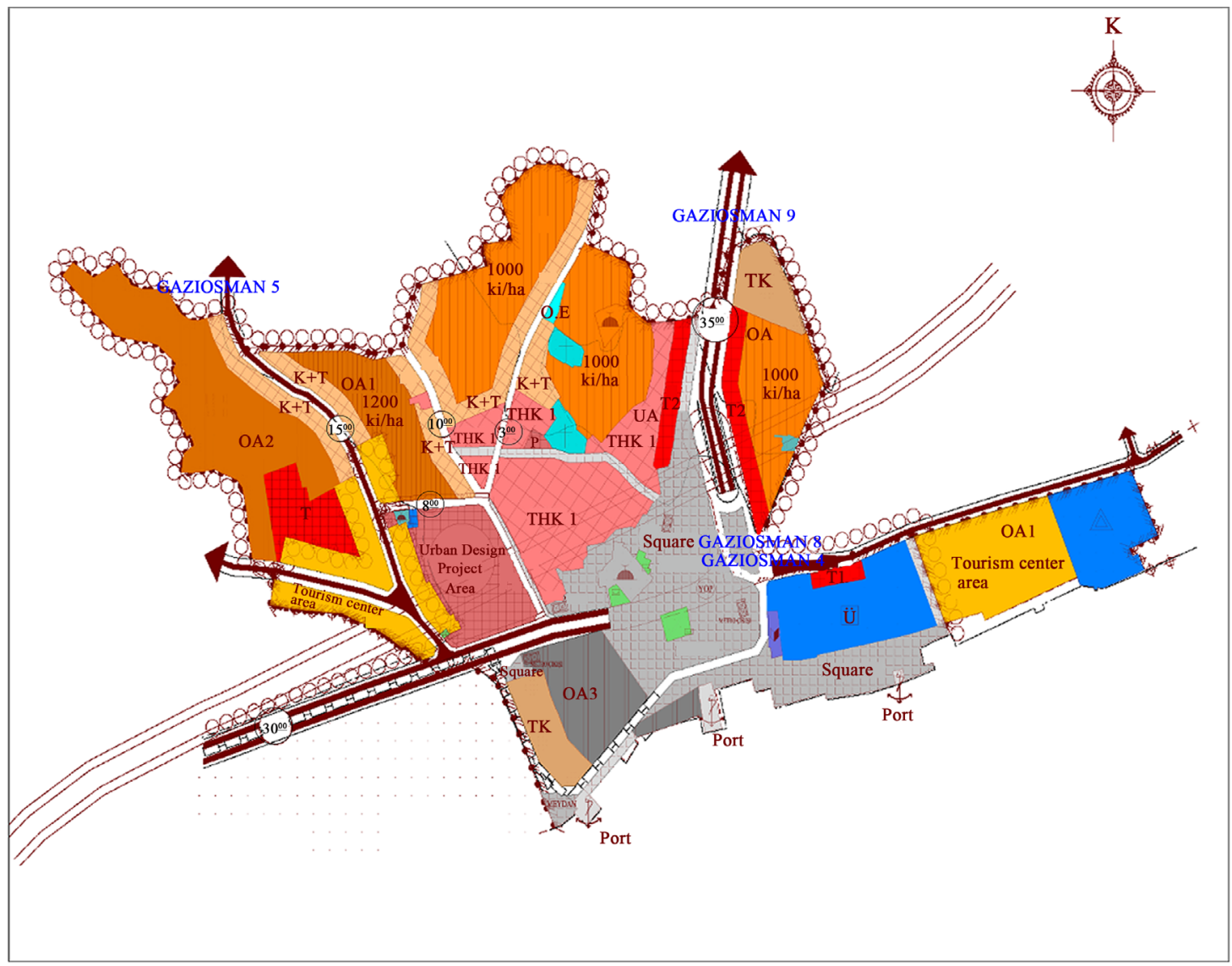

\section{LEGEND}

\section{Borders}

Master plan border
transition area border
Railway axis
Subway

\section{Urban Facilities}

Tourism center areas
Commercial areas
Commercial areas (Hmax: $15.50 \mathrm{~m}$ )
Commercial areas (Hmax: $18.50 \mathrm{~m}$ )

개 1 Commercial-service-culture areas (Hmax: $12.50 \mathrm{~m}$ )

THK 2 Commercial-service-culture areas (Hmax: $15.50 \mathrm{~m}$ )

$x+r$ Ground floor commercial areas

Tourism accomodation areas

Urban design project areas

Marketing area

Military area

Religious buildings: Mosque

Religious Buildings: Church

\section{$\underline{\text { Housing Areas }}$}

High-density housing areas

Higher-density housing areas

Urban Green Areas

Cemeteries and trsuary areas

Urban Social Infrastructure Areas

Health facility areas

OE Special education areas

0 Campus areas

Highschool facility areas

Urban Technical Infrastructure Areas

xnow Squares

Maritime lines port

350 $11^{\text {st }}$ stage roads and regional roads

$20^{\circ}-2^{\text {nd }}$ stage roads and collector-distrubutor roads

(0) $-3^{\text {rd }}$ stage roads

Appendix 1. Sinanpasa district 1/5000 scale conservation master zoning plan (Besiktas municipality). 
Appendix 2. Demographic profiles of survey participants.

\begin{tabular}{|c|c|c|}
\hline Demographic Structure & Frequency & Percentage (\%) \\
\hline \multicolumn{3}{|l|}{ Gender } \\
\hline Female & 80 & 60.6 \\
\hline Male & 52 & 39.4 \\
\hline \multicolumn{3}{|l|}{ Age } \\
\hline$<21$ & 21 & 15.9 \\
\hline $21-30$ & 62 & 47 \\
\hline $31-40$ & 21 & 15.9 \\
\hline $41-50$ & 11 & 8.3 \\
\hline $51-60$ & 6 & 4.6 \\
\hline$>60$ & 11 & 8.3 \\
\hline \multicolumn{3}{|l|}{ Education Status } \\
\hline Primary School & 10 & 7.6 \\
\hline Middle School & 4 & 3 \\
\hline High School & 26 & 19.7 \\
\hline College & 2 & 1.5 \\
\hline University & 74 & 56.1 \\
\hline MSc & 13 & 9.9 \\
\hline Doctorate & 3 & 2.3 \\
\hline \multicolumn{3}{|l|}{ Place of Birth } \\
\hline Istanbul & 62 & 47 \\
\hline Outside of Istanbul & 70 & 53 \\
\hline \multicolumn{3}{|l|}{ Duration of Residence in Istanbul } \\
\hline 0 - 5 Years & 30 & 22.7 \\
\hline 5 - 10 Years & 18 & 13.6 \\
\hline 10 - 20 Years & 22 & 16.7 \\
\hline 20 - 30 Years & 36 & 27.3 \\
\hline 30 - 40 Years & 8 & 6.1 \\
\hline$>40$ Years & 18 & 13.6 \\
\hline
\end{tabular}

Appendix 3. Usage experience of the survey participants in Besiktas.

\begin{tabular}{lcc}
\hline \multicolumn{1}{c}{ Participants' Relation with Besiktas } & Frequency & Percentage (\%) \\
\hline Arrival Reason of Participants to Besiktas & & \\
Entertainments, Shopping & 50 & 37.9 \\
Work & 14 & 10.6 \\
Residence & 57 & 43.2 \\
Education Status & 11 & 8.3 \\
\hline
\end{tabular}




\section{Continued}

\section{Weekly Arrival Rate of Participants to Besiktas}

Rarely

$24 \quad 18.2$

1 - 2 times per week

21

3 - 4 times per week

5 - 6 times per week

$10 \quad 7.6$

Everyday

Crime Victimization

Yes

No

Crime Victimization of Relatives

Yes

No

111

Appendix 4. Safety status in Besiktas.

\begin{tabular}{lcc}
\hline \multicolumn{1}{c}{ Participants' Safety Perception } & Frequency & Percentage (\%) \\
\hline Daytime Safety & 109 & 82.6 \\
Safe & 23 & 17.4 \\
Unsafe & & \\
Night Safety & 82 & 62.1 \\
Safe & 50 & 17.4 \\
Unsafe & & \\
Crime Victimization & 17 & 12.9 \\
Yes & 115 & 87.1 \\
No & & \\
Fear of Roam Alone & 8 & 6.1 \\
Afraid & 124 & 93.9 \\
Not Afraid & & \\
Standing in Awe of Some Streets & 46 & 60.72 \\
Afraid & 86 & 39.28 \\
Not Afraid &
\end{tabular}

Appendix 5. Unsafety causes of survey participants.

\begin{tabular}{lcc}
\hline \multicolumn{1}{c}{ Causes of Unsafety } & Frequency & Percentage (\%) \\
\hline Daytime & 10 & 42 \\
Terrorist Incidents & 4 & 17 \\
Crowd & 3 & 13 \\
Purse Snatching Risk & 3 & 13 \\
Commotion & 1 & 4 \\
Possibility of Protest & 1 & 4 \\
Presence of Substance-Dependent Contacts & 1 & 4 \\
Immigrants & 1 & 4 \\
Hooligans & & \\
\hline
\end{tabular}




\section{Continued}

\begin{tabular}{lll}
\hline Night & & \\
Presence of People Who Use Alcohol & 7 & 18 \\
Desolateness & 6 & 15 \\
Presence of Substance-Dependent Contacts & 5 & 13 \\
Lack of Trust to People & 5 & 13 \\
Terror Incidents & 4 & 10 \\
Exposed to Crime Already & 3 & 8 \\
Crowd & 2 & 5 \\
Immigrants & 1 & 3 \\
Verbal Harassment & 1 & 3 \\
Pickpockets & 1 & 3 \\
Commotion & 1 & 3 \\
Stray Dogs & 1 & 3 \\
Hooligans & 1 & 3 \\
\hline
\end{tabular}

Appendix 6. Unsafe areas for survey participants.

\begin{tabular}{lcc}
\hline Terrifiying Areas for Participants & Frequency & Percentage (\%) \\
\hline Street/Zone Name & 13 & 28 \\
\hline Besiktas Bazaar Region & 7 & 15 \\
Besiktas Square & 5 & 11 \\
Ihlamurdere Street & 4 & 9 \\
Mumcu Bakkal Street & 4 & 9 \\
Sinanpaşa Environment & 2 & 4 \\
Misırlı Bahçe Street & 2 & 4 \\
Dolmabahçe Avenue & 2 & 4 \\
Beşiktaş Avenue & 1 & 2 \\
Salihefendi Street & 1 & 2 \\
Şair Veysi Street & 1 & 2 \\
Tuzcubaba Environment & 1 & 2 \\
Hasfirın Street & 1 & 2 \\
Şair Nedim Street & 1 & 2 \\
Afacan Street & 1 & 2 \\
Barbaros Boulevard & & 2 \\
\hline & & 2 \\
\hline
\end{tabular}

Appendix 7. Survey participants' post renewal safety perception.

\begin{tabular}{lcc}
\hline Renewal Effect & Frequency & Percentage (\%) \\
\hline Post-Renewal Safety Perception & & \\
\hline Impartiality & 99 & 75 \\
Positive & 22 & 16.7 \\
Negative & 11 & 8.3 \\
\hline
\end{tabular}




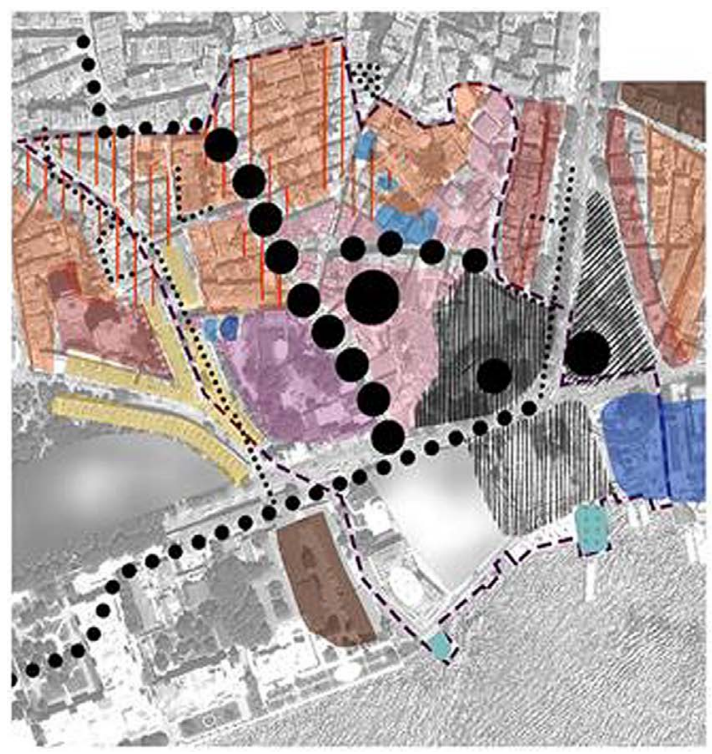

\section{LEGEND}

--- Sinanpaşa Neighborhood Border Housing Area

Urban Design Project Area

Tourism Central Area

Commercial-Service-Culture Area

Tourism Accomodation Area

Pier

Religious Buildings (Church)

Campus Area

Religious Buildings (Mosque)

III] Ground Floor Commercial Area

Itinili| Square

Fear of Crime/People

110 pt: 13

$90 \mathrm{pt} 7$

70 pt: 5

- 50 pt: 4

- $30 \mathrm{pt}: 2$

$10 \mathrm{pt}: 1$

Appendix 8. Land use in Sinanpasa Mahallesi and Mentioned Streets in the manner of fear by participants (Köklü, 2016).

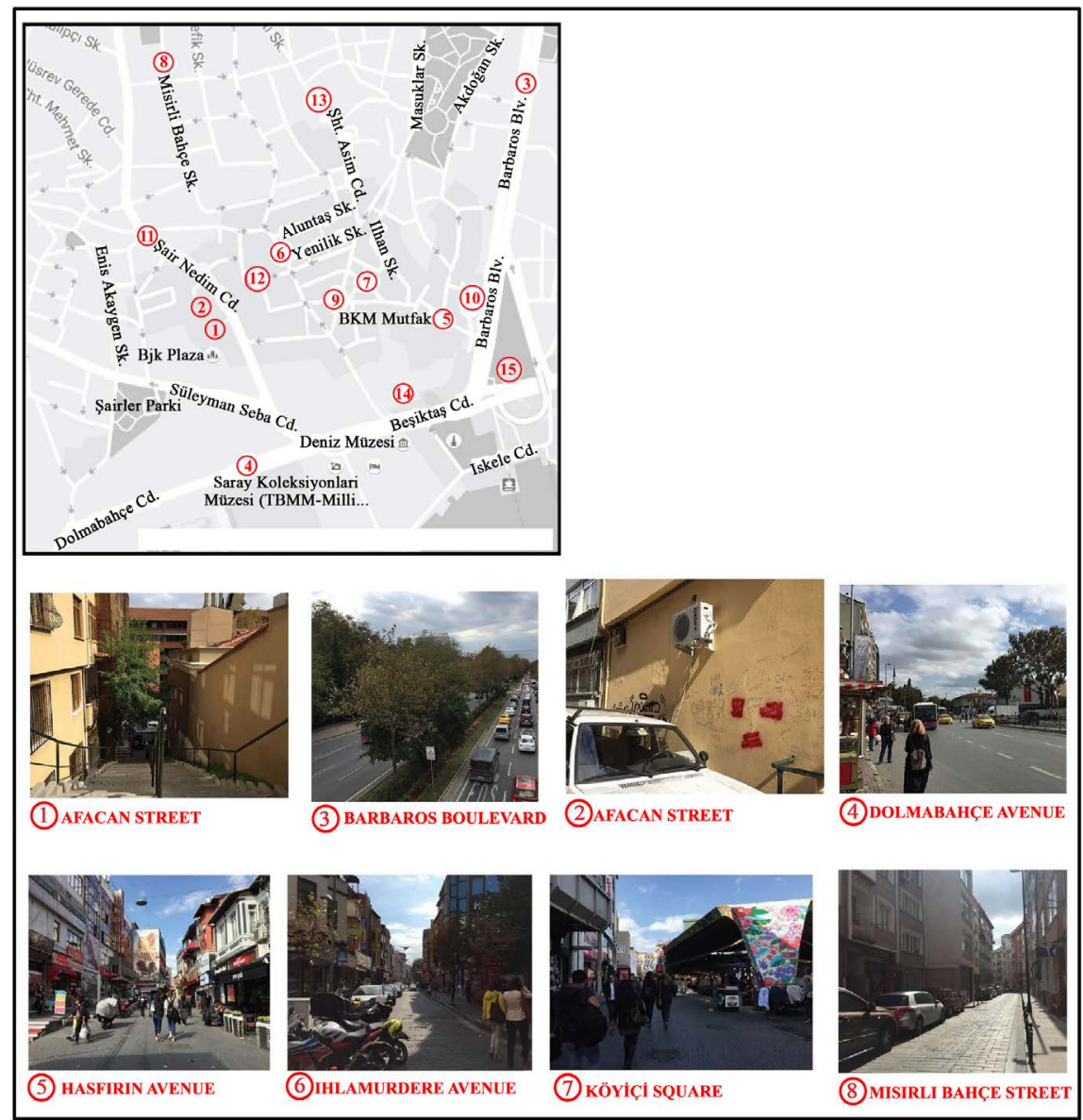

Appendix 9. Photographs of the streets where the participants in the Sinanpaşa Neighborhood indicated that they were afraid (Köklü, 2016). 


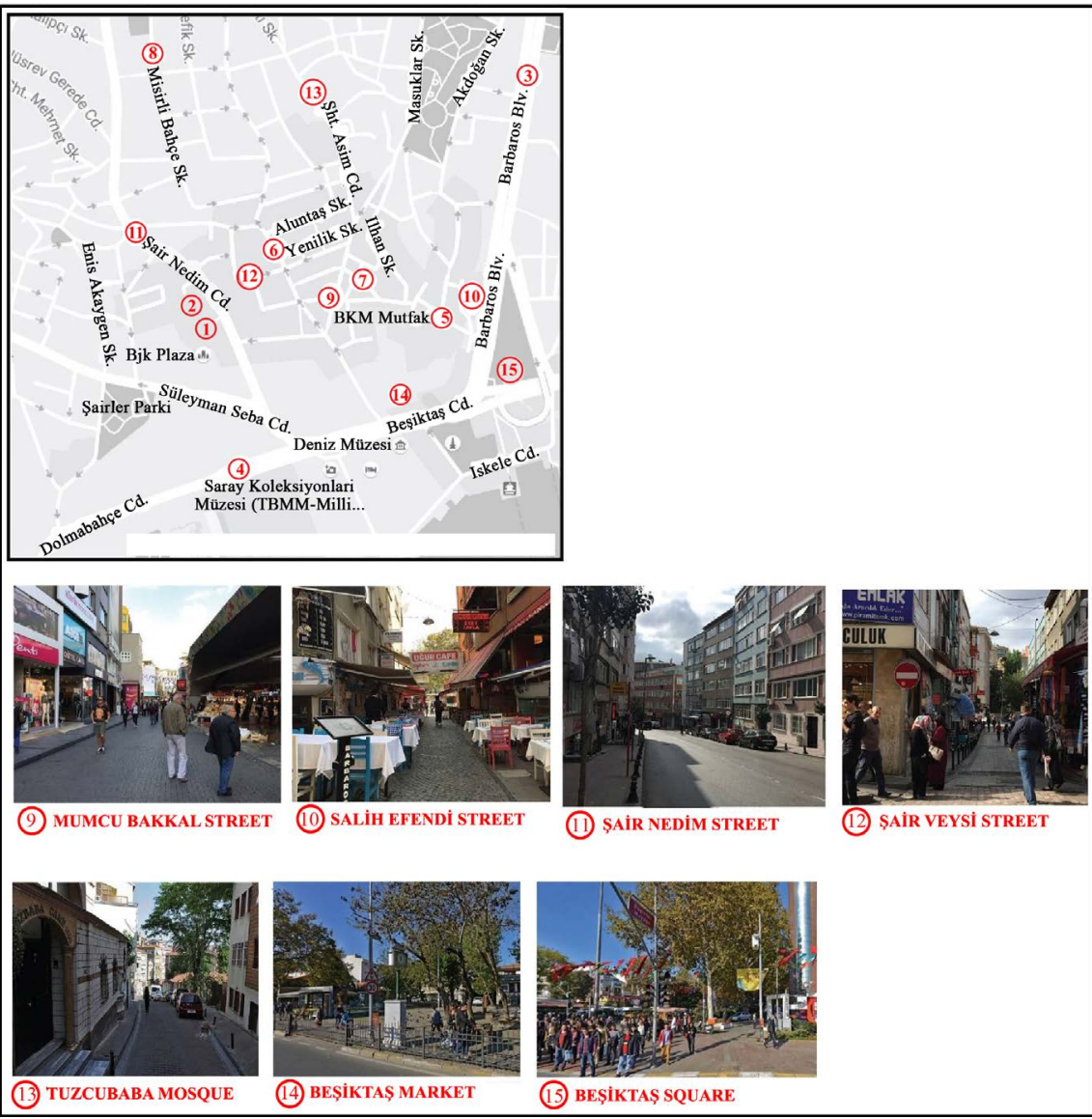

Appendix 10. Photographs of the streets where the participants in the Sinanpaşa Neighborhood indicated that they were afraid (Köklü, 2016).

\section{Scientific Research Publishing}

Submit or recommend next manuscript to SCIRP and we will provide best service for you:

Accepting pre-submission inquiries through Email, Facebook, LinkedIn, Twitter, etc. A wide selection of journals (inclusive of 9 subjects, more than 200 journals)

Providing 24-hour high-quality service

User-friendly online submission system

Fair and swift peer-review system

Efficient typesetting and proofreading procedure

Display of the result of downloads and visits, as well as the number of cited articles Maximum dissemination of your research work

Submit your manuscript at: http://papersubmission.scirp.org/

Or contact cus@scirp.org 